\title{
A PRIVATE (INTERNATIONAL) LAW PERSPECTIVE COMMENT ON “A NEW JURISPRUDENTIAL FRAMEWORK FOR JURISDICTION”
}

\author{
Horatia Muir Watt*
}

What follows is a private international lawyer's response to the thought-provoking ideas put forward by Professor Svantesson on international jurisdiction from a criminal law perspective. ${ }^{1}$ This stance may in itself seem (and certainly feels!) paradoxical, since much contemporary academic effort (my own included) has been directed towards a rejection of the public/private distinction in international law. This rejection has been championed both as a normative matter, because so much would be gained from reaching "beyond the schism" to overcome the personality split from which the discipline has suffered for over a century, as well as a descriptive matter, since multiple issues, debates, myths and concepts straddle the divide, even if they give rise to specific disciplinary understandings on either side. Both of these observations apply to jurisdiction in all the forms mentioned by Professor Svantesson. Moreover, the need for an intradisciplinary conversation is particularly acute in respect of international limits on criminal jurisdiction, which, as Professor Svantesson's paper seems to demonstrate, fall somewhere in-between the public and the private models (perhaps seen as logically public, but considered private in France!).

From a private international law perspective, Svantesson's piece evokes a strong impression of déjà vu (and justifies recalling the evolution of the law of jurisdiction on the other side of the schism). My comment begins with this point, then explores the causes of a traditional décalage in international criminal law in this respect and suggests why this matters. I then suggest that the changes advocated seem unlikely to fulfil their ambitious promise of paradigm renewal; I conclude with a short musing about what a radical overhaul of the law of jurisdiction would actually look like.

\section{Déjà Vu?}

The dominant impression that emerges from reading Professor Svantesson's paper is one of déjà vu, both with regard to conflict of laws doctrine and to general public international law. The gist of his analysis is that the foundational principles for concurrent and optional (as opposed to exclusive and compulsory) criminal jurisdiction laid out in the Harvard Draft in 1935, comprising notably territory and nationality, were originally mere proxies for more elaborate core ideas involving the search for "substantial connections" and "legitimate state interests." It is back to these (adding other relevant interests such as those of the international community) that we might usefully return today, discarding the dogmatic trappings and the jurisprudential value which the proxies acquired over time. As an illustration of the need for reform, he cites the wholly apt example of the current dispute over data privacy between Microsoft and the U.S. Government. In this case, in order to justify

\footnotetext{
* Full professor at Sciences-Po Paris and Co-Director of the Program "Global Governance Studies".

Originally published online 03 November 2015.

${ }^{1}$ Dan Jerker B. Svantesson, A New Jurisprudential Framework, for Jurisdiction: Beyond the Harvard Draft, 109 AJIL UNBOUND 67 (2015).
} 
or contest a search warrant issued under the Electronic Communications Privacy Act of 1986, each party makes out an equally plausible case for the territorial (and legal) or extraterritorial (and illegal) reach of the intended enforcement. Professor Svantesson then observes "that we are no longer, if we ever were, able to draw sharp lines between what is territorial and what is extraterritorial."

This would certainly be difficult to dispute. That territory—or territoriality, its metaphorical projection onto jurisdiction, and its opposite, extraterritoriality - is both indeterminate, flippable, and increasingly irrelevant, is not news in other domains of international law. Similar conclusions have been reached for a long time now within the conflict of laws, over the "private" side of the fence. At the time of the Harvard Draft, private international law subscribed to an identical "grid-like" scheme, but jettisoned it by the 1970s—replacing it with the very same set of "core ideas" which Professor Svantesson excavates here from underneath the overly dogmatic principles of territory and nationality. Indeed, 1935, the year of the Harvard Draft, followed the publication, in the United States, of the First Restatement of the Conflict of Laws, in which the implications of territory as a jurisdictional principle were spelt out in detail in interstate conflicts of (private) laws. However, it fell victim very soon afterwards to the attacks of legal realism. By the 1960s, the virtues of "mechanical jurisprudence" were unmasked during the U.S. "functionalist revolution" in the field. Since territory had been used to justify more or less any outcome — as the argument went - it could provide little guidance for solving conflicts of laws relating to complex torts; the proper reach of each conflicting claim was more plausibly defined, therefore, by policy concerns. In the early 1970s, the Second Restatement reflected this radical change from "power" to "policy": substantial connections, governmental interests, and more diffuse interests of interstate commerce or international legal order — the three guidelines advocated by Professor Svantesson—had replaced any reference to territoriality. Methodologically, meanwhile, open-ended, flexible, and balancing-style techniques eclipsed hard-and-fast, rule-based, definitions of scope. These ideas mushroomed too, by capillarity, over the other side of the Atlantic, merging gradually with the quest for "the seat of the legal relationship" in the continental tradition, in which territory had played a far lesser role to begin with.

Similar trends also migrated from interstate conflicts to the international reach of federal regulatory law. In the name of congressional intent, the scope of antitrust or securities regulation began to be measured no longer by the yardstick of territory but by an "effects" test, or other incarnations of the "reasonable", which had already been instated as a guiding principle by the Third Restatement of Foreign Relations Law in the United States. The parallel between conflict of laws doctrine and perceptions of the extraterritorial potential of federal regulatory jurisdiction is unsurprising. Indeed, by the 1980s, private international law's public counterpart, whose authority was involved by implication in these cases, had gone a long way along the same path. Territory could not survive in this brave new world as an allocatory principle, too closely bound up as it was with prerealist conceptions of order, hierarchy and sovereign equality. Rules and their "mechanical jurisprudence" were swept away by flexible standards in new regulatory fields comprising a variety of civil, criminal and administrative sanctions (such as antitrust/competition or capital markets) which also came replete with brand new policyanalysis and balancing techniques.

Territory did not wait for the internet, either, to prove inadequate in defining jurisdiction in civil cases with criminal overtones, where geography clearly counted less and less: money laundering, financial fraud, trafficking (in cultural objects, children or human organs) joined more familiar transnational "toxic torts" and cross-border invasions of privacy, at the nexus between the public and the private, soliciting the resources of both branches of international law. The coming of cybertorts, with cultural values colliding dramatically in global virtual space, only confirmed the need for a methodological overhaul. Only very recently has territoriality resurfaced, however, in a spectacular backlash against the open-ended or functional approaches which these intrinsically de- 
territorialised jurisdictional conflicts seemed to call for. The move took place in the case-law of the U.S. Supreme Court in relation to capital market fraud, ${ }^{2}$ and soon afterwards into the human rights context. ${ }^{3}$ It is here that the intradisciplinary conversation on jurisdiction is most needed, since it seems likely this surprising and arguably regressive development was largely induced, or facilitated, by the criminal dimension of these ostensibly civil claims. Before we turn to this hypothesis in more detail, it may be useful to point out that even in this new context, most would acknowledge that territory has to be the proxy for something such as "national interests." Here again, Professor Svantesson's thesis is highly plausible, but uncontroversial. The question remains, nevertheless, as to the circumstances in which national interests are deemed to be involved. So while a return to core considerations is undoubtedly salutary, as is the discarding of dogma, it is an illusion to expect that a reference to legitimate state interests, substantial connections or the weighing of other miscellaneous considerations will prove any more tractable.

Why The Décalage?

But how far is all this relevant in respect of criminal jurisdiction, anyway? Several reasons might explain why criminal jurisdiction calls for a differential treatment; none is really convincing. Thus, if the Harvard Principles are still the jurisprudential yardstick against which jurisdictional claims in criminal law are assessed, untouched by the trends observed in other domains of international law, it may be, first of all, because such claims are tightly bound up with issues of enforcement, an area in which the more flexible approaches appropriate to prescriptive jurisdiction (or issues of governing law) seem to stall. But as the Microsoft warrant example cited by Professor Svantesson shows, seizure of dematerialized assets and virtual discovery muddle the frontiers between prescription and enforcement, at the very same time as they raise the question of what territoriality really means in the context of cybercrime. As various forms of "extraterritorial" injunctive relief have long shown in respect to investigative, provisional or evidentiary measures in civil litigation, when sovereign power can be deployed without physical intervention abroad, the very concept of enforcement is shaken-and the territorial monopoly besides.

A second consideration is linked to the idea that things have changed radically with the internet. Of course, the internet is an urgent reason to rethink territory as a jurisdictional principle, as Professor Svantesson suggests, since cybercrimes, like cybertorts, are ubiquitous, and subject as such to multiple regulatory claims. The implication of this argument is that in the physical world, things are different; territory could presumably live along happily as before. However, the difficulties of using territory in virtual space are largely analogous to those, mentioned above, which classical conflict of laws theory encountered half a century ago, when torts began to be intrinsically (and not simply accidentally) cross-border, involving issues like pollution, privacy, intellectual property, and financial fraud. In such cases, territory is similarly impotent to govern any conflicting assertions of jurisdiction, whether or not in virtual space. During the past decades, courts have devoted much energy to balancing out contradictory policy considerations in order to solve jurisdictional collisions. Whether framed as a problem of conflict of laws, of judicial jurisdiction (general, special, etc.), or of the international reach of public law, precise criteria are difficult to come by. Linked to the fact that contemporary conflicts are framed increasingly in terms of colliding fundamental rights (whether of constitutional or international source), the arrival of proportionality on the scene brings such balancing processes to the surface. The only real change

2 Morrison v. National Australia Bank, 561 U.S. 247 (2010).

3 Kiobel v. Royal Dutch Petroleum Co., 133 S.Ct. 1659 (2013).

${ }^{4} \underline{I d}$. at, $1670-1677$ (Breyer, J., concurring). 
here is in an increased awareness of the contingency and relativity of outcomes. As Professor Svantesson observes in relation to the Microsoft warrant case, insofar as they relate to the definition of territory, "both claims are plausible." Well, yes ... . Territory can mean many things or nothing at all, depending on how lines are drawn or how the metaphor of territoriality works out in different circumstances.

A third apparently obvious reason for which criminal jurisdiction might remain apart is that it concerns the exercise of police power, or the power to punish, an issue on which sovereigns are particularly sensitive. It is one thing to decide platonically, as a matter of prescriptive jurisdiction (or as an issue of the determination of governing law), the acceptable reach of a given statute or judgment. It is quite another to define in absolute terms the reach of state power to repress. There is a difference, then, between solving a conflict of laws over, say, a cybertort involving invasion of privacy, and determining the extent of state power to apply appropriate criminal sanctions in such a case. Or is there? In instances of complex conduct with broad consequences, it is difficult to see where the difference actually lies when it comes to determining the criteria with which to decide among competing claims by several states. It is not entirely clear that criminal law's intimate involvement with police power really justifies that it should stand apart from the general loosening up of jurisdictional parameters which has taken place in public international law over the past half-century, in respect of prescriptive or adjudicatory jurisdiction. It would make sense, then, if not to blindly align, at least to open criminal jurisdiction to the type of reflexion that has taken place in other spheres. But there may be more at stake.

\section{Does It Matter, Anyway?}

The fact that criminal jurisdiction has remained to date in the throes of territoriality, as Professor Svantesson shows, could shed at least a partial light on the current backlash, mentioned above, against the more flexible, open-ended approaches recorded within the other fields of international law. In recent decades, there has been a remarkable surge of transnational tort claims for human rights violations, beginning, spectacularly, with the Alien Tort Statute litigation in the United States and slowly spreading to other jurisdictions that are home to multinational corporate defendants. Arguably, such claims either fall within the remit of general public international legal conceptions of prescriptive jurisdiction, or appear as conflict of laws in tort. If the rights in question are enshrined in international law (ius cogens, custom, or texts), the problem can be formulated as one of reach of state authority to protect them depending on where they were committed, or as one of determining the law applicable to the remedy. Both approaches appear in comparative case-law and are clearly present, and indeed entwined, in the various stages of the Kiobel litigation, which culminated in the landmark 2013 decision of the U.S. Supreme Court. Here, territoriality (or the unrebutted presumption against extraterritoriality) makes a come-back in the name of foreign policy concerns (the fear of "unintended clashes between our laws and those of other nations which could result in international discord")—even though it was not regulatory enforcement that was involved here but the principle of liability for corporate human rights abuse abroad. It is no doubt the presence of the human rights component which introduced considerations specific to criminal jurisdiction to these (formally) civil cases. Analyses belonging to criminal law (including the highly controversial criminal liability of corporations) spilled over onto civil (tort) grounds, influencing perceptions of the limits of prescriptive jurisdiction. There is a certain conceptual confusion here, if not a deliberate recourse in the context of civil claims to the substantially more conservative perspective of international criminal jurisdiction.

There are, then, significant stakes in making a deliberate connection between these various conceptions in order to understand why they should, or should not, coincide. Indisputably, as Professor Svantesson believes, a conceptual revision is needed. And as far as they go, his proposals in respect of criminal jurisdiction are eminently sensible: of course, territory is inadequate to define jurisdiction today, as it was banished as such long ago from neighbouring fields; moreover, it surely stands as proxy for "core concerns" in terms of connections, 
state and other policy interests, many of which have been made explicit since the 70s. But his proposal does not go far enough. What Professor Svantesson advocates as a "new paradigm" for redefining criminal jurisdiction does not seem likely to fulfil its promise in this respect. If there is to be a paradigm change, there must surely be more to it than a refocusing on "substantial connections", or "legitimate state interests", or further diffuse policy considerations, all of which were already around for some time in a preglobal world. The most challenging question today for international lawyers is the question of the ways in which the very existence of international law (whether public, criminal, administrative or private) in all its conceptual components (jurisdiction, sovereignty, and legal order) is radically threatened by globalization, which transforms processes of law production, displaces authority, neutralises boundaries. Therefore, while a radical conceptual overhaul is certainly long overdue in respect to the extraterritorial assertion of sovereignty, a return to familiar forms of state interest analysis is not necessarily the best way to go about it. I appreciate that Professor Svantesson's proposal is limited to this one point about the desirable re-interpretation of the Harvard Draft principles, and that even while broaching paradigm renewal, he did not intend to wade any deeper into the relationship between international law, public, criminal or private, and global legal theory! However, since he uses the vocabulary of epistemology, it is not inappropriate to respond on the same plane, particularly since this is precisely where debate seems to be heading over the other side of the fence. In a nutshell, from over the private international side of the fence, it seems that "we've been there" . . . and left long since . . . for a more interdisciplinary horizon.

\section{Towards Interdisciplinary Overhaul}

It is certainly important to guard against the trivialization of paradigm change (in law or elsewhere). In this respect, it is very doubtful that a change from territory as dogmatic principle to the open-ended formulation of connections and interests constitutes an epistemological upheaval of sufficient significance to qualify as a change in legal consciousness. This does not mean, however, that contemporary globalization does not affect international law in a paradigmatic way. Traditionally, the ordering of competing normative claims outside any particular domestic system was sought in (public or private) international law. International law was understood both to provide an overall scheme of intelligibility whereby to understand other social spheres and to make available operational tools with which to define authority, allocate responsibilities, and guide the conduct of public and private actors. However, the emergence of competing, diffuse (post-Westphalian) forms of authority beyond the state — crossing over state boundaries, originating outside or independently of them — challenges the law in these ordering functions. In the wake of displacements of power from public to nonstate actors (such as multinationals, credit-raters, or standard-makers), struggles for legitimacy occur between state-bound or endorsed legal systems and other unidentified flying sources. Moreover, sovereignty, the foundational concept of the international and domestic legal order, appears inverted or subverted, signifying obligations towards the international community rather than supremacy.

Rising to the challenge of globalization, alternative disciplinary vocabularies with exciting new "intimations" of novel forms of law have arrived on the scene. ${ }^{5}$ They are displacing international law in the intellectual debate, since it no longer delivers on a world-vision with which to make sense of global chaos and does not seem to any longer ask the right questions or even use an adequate epistemology. The focus on states leaves too much out of the picture. New legal theoretical approaches are self-consciously global and largely pluralist. One of the comparative attractions of global legal pluralism is to reflect in its methodology the intense circulation of ideas and the constant mutual irritation, the "in-between worlds" which "interlegality" produces. So does this

5 Neil WALKer, Intimations of Global LAW (2014). 
mean, in the end, that international law, private and public, are ultimately irrelevant, as products of modernity that are not as it were "late" enough to deal with "liquid" forms of sovereignty. ${ }^{6}$ While this may indeed be so, there are signs that the problems they have been trying to solve are more present than ever, in renewed forms. The central problem singled out by contemporary legal pluralism is framed in terms of competing norms and claims to authority, while proposed solutions for their mutual accommodation take the form of deference, coordination or synthesis, and competition.

In short, the terms defined, the methods used, the values involved, and the diversity described in our global moment, are all to a certain extent familiar to the (often premodern) history of the conflict of laws and the law of nations, in one era or another. It is hardly surprising, therefore, that international legal methodology in its allocative function - albeit substantially revisited-, has attracted new attention, to the point of being mooted as the only plausible content of "global societal constitutionalism." If encounters between heterogeneous norms or expressions of diverse types of informal authority are central to the understanding of the normative landscape beyond the confines of state sovereignty, the traditional schemes of intelligibility which underlie international law need to take on board various additional dimensions of global complexity. If international law does so and succeeds in living up to this challenge, it may emerge considerably enlightened. This is precisely why rethinking jurisdiction in international law needs to go so much further. Professor Svantesson is to be thanked, therefore, for providing an opportunity not only to peer over the fence from a private international law perspective, but also to muse on our common horizon.

${ }^{6}$ See Zygmunt Bauman, Liquid Modernity (2014).

7 Gunther Teubner, Constitutional Fragments: Societal Constitutionalism and Globalization (2012). 